\title{
THE APPLICATION OF THE OPTICAL DENSITY OF SARCOPLASM OF THE SKELETAL MUSCLE FOR A DETERMINATION OF THE PRESCRIPTION OF INJURIES IN MEDICOLEGAL PRACTICE
}

\begin{abstract}
V.K. Sokol
Abstract. A search and improvement of the methods of a medicolegal examination in relation to the prescription of the origin of injuries of the soft tissues, in particular, the skin and muscles, stipulate a necessity of studing of new aspects in the dynamics of an inflammatory process for a substantiation and elaboration of the necessary criteria which will allow to solve questions about the prescription of injuries.
\end{abstract}

Key words: forensic medicine, injury, diagnosis, muscles, optical density.

National Medical University (Kharkiv)

Рецензент - проф. В.Т. Бачинський

Buk. Med. Herald. - 2013. - Vol. 17, № 3 (67), part 1. - P. 159-161

Надійшла до редакції 05.06.2013 року

(C) В.К. Сокол, 2013

УДК 340.6-378.046.4

С.Л. Соколова, О.Б. Долгова, Н.В. Пермякова, Г.А. Вишневский

\section{ПРИМЕР МОДЕЛИ ФОРМИРОВАНИЯ ПРОГРАММЫ ДОПОЛНИТЕЛЬНОГО ПРОФЕССИОНАЛЬНОГО ОБРАЗОВАНИЯ ВРАЧЕЙ ПО СПЕЦИАЛЬНОСТИ «СУДЕБНО-МЕДИЦИНСКАЯ ЭКСПЕРТИЗА»}

Уральская государственная медицинская академия, г. Екатеринбург, Россия

Резюме. В работе приведен пример формирования программы дополнительного профессионального образования по специальности «Судебно-медицинская экспертиза» с учетом мнения потребителей образователь- ных услуг и потребностей экспертной практики, представлен опыт реализации программы.

Ключевые слова: дополнительное профессиональное образование, судебно-медицинская экспертиза.
Актуальность и необходимость совершенствования методологии и системы организации профессионального медицинского образования, в том числе и последипломного обучения врачей судебно-медицинских экспертов, определена постоянным изменением условий и потребностей рынка труда, значительными качественными и количественными изменениями научнотехнической информации, потребностью специалистов в совершенствовании, увеличении и доступности профессиональных знаний на протяжении всей трудовой деятельности. Стратегия развития ГБОУ ВПО «Уральская государственная медицинская академия», работа в системе менеджмента качества, ориентированность конечного результата образовательного процесса на удовлетворение запроса потребителей образовательных услуг предопределили особенности создания и реализации программы дополнительного профессионального образования по специальности «Судебно-медицинская экспертиза» - «Вопросы патоморфологии и судебно-медицинской оценки некоторых заболеваний и состояний».

Подготовка программы дополнительного профессионального образования по специальности «судебно-медицинская экспертиза», оценка ее эффективности осуществлялись в несколько этапов: 1) планирование и проектирование цикла, 2) реализа- ция программы цикла общего усовершенствования, 3) анализ результативности, 4) планирование и выполнение корригирующих мероприятий.

Формирование программы на первом этапе проводилось в соответствии с потребностями экспертной практики, запросами врачей судебно-медицинских экспертов и администрации экспертного учреждения. С помощью анкетирования были определены проблемы послевузовской подготовки по специальности «судебно-медицинская экспертиза», проанализированы мнения судебно-медицинских экспертов территориальных субъектов РФ (Уральского федерального округа, Республики КОМИ и Пензенской области), а также сотрудников кафедр судебной медицины высших профессиональных образовательных медицинских учреждений, территориально расположенных в указанных регионах РФ.

Оптимальной формой обучения при повышении профессиональной квалификации более $40 \%$ врачей для себя видят очный цикл усовершенствования на базе медицинского ВУЗа, располагающегося в регионе, а четверть респондентов считают целесообразным сочетание очной и заочной форм обучения на базе медицинского высшего профессионального образовательного учреждения региона.

Формирование тематического плана занятий для слушателей цикла в системе дополнительно- 
го профессионального образования выполнялось с учетом мнения судебно-медицинских экспертов о наиболее сложных для них объектах исследования, а также мнения основных потребителей результатов деятельности судебно-медицинской службы о качестве и трудностях при производстве судебно-медицинской экспертизы. Многофакторный всесторонний анализ данных позволил определить блок проблем, актуальных в настоящее время для судебно-медицинской экспертной практики, на основе чего был составлен тематический план занятий и определены следующие модули учебной программы:

Менеджмент качества в государственных бюджетных учреждениях здравоохранения - Бюро судебно-медицинской экспертизы: современные подходы к оценке качества экспертной деятельности; роль внутренних аудитов в повышении качества работы экспертов.

Танатогенез. Диагностика непосредственных причин смерти при травмах и заболеваниях. Диагноз как один из критериев стандартизации в здравоохранении.

Ненасильственная смерть в практике судебно-медицинских экспертов: особенности тактики, диагностики, оценки роли травмы и патологии в генезе смерти.

На этапе реализации программы цикла общего усовершенствования во время обучения на кафедре судебной медицины Уральской государственной медицинской академии, расположенной на базе Свердловского областного бюро судебномедицинской экспертизы, предлагается цикл лекционных занятий, практические и семинарские занятия, в том числе, и в секционном зале. Для чтения лекций по отдельным, наиболее востребованным в экспертной практике разделам патологической анатомии, инфекционных болезней, нейрохирургии приглашаются преподаватели Уральской государственной медицинской академии, имеющие ученую степень доктора медицинских наук, звание профессора.

Опыт работы профессорско-преподавательского состава кафедры судебной медицины в отделах бюро судебно-медицинской экспертизы Свердловской области, позволил при проверке экспертных документов выявить и проанализировать ошибки, встречающиеся в практике врачей судебно-медицинских экспертов, определил возможность проведения практических занятий по оценке качества работы врачей судебномедицинских экспертов с использованием заключений экспертных комиссий. Часть практических занятий проводится в форме конференции с анализом экспертных случаев, явившихся диагностически сложными для судебно-медицинских экспертов - слушателей цикла.

В тематический план цикла усовершенствования включены практические занятия в секционном зале отдела экспертизы трупов и в отделении патологии детского возраста «Уральского научно-исследовательского института охраны материнства и младенчества Федерального агентства по высокотехнологичной медицинской помощи». Занятия проводятся в форме мастерклассов по освоению методик исследования трупов детей раннего возраста, методов исследования сердца, подходов к исследованию скелетированных трупов и т.п.

Кроме того, программой предусмотрен раздел самостоятельной работы слушателей цикла усовершенствования, который включает в себя реферативную работу или подготовку мультимедийной презентации по предлагаемой тематике с последующей защитой на зачетном занятии. Для повышения эффективности процесса самообучения слушателей коллективом кафедры издан сборник ситуационных задач и тестовых заданий по судебно-медицинской экспертизе.

На этапе оценки эффективности образовательной программы по окончании циклов усовершенствования преподавателями кафедры проводятся анализ, систематизация и выявление степени удовлетворенности врачей судебно-медицинских экспертов уровнем преподавания на цикле общего усовершенствования, необходимых для последующих управленческих и педагогических решений.

Изучение мнения о качестве преподавания на кафедре судебной медицины, взаимодействии со слушателями в процессе обучения, осуществлялось посредством опроса (анкетирования) врачей судебно-медицинских экспертов.

Результаты опроса продемонстрировали, что организация учебного процесса на кафедре судебной медицины получила высокую оценку. Отмечено, что на занятиях практически всегда наглядно представляется современная информация, позволяющая приобрести новые знания. При ответе на вопрос о последующем возможном использовании в практической деятельности полученных знаний, отработанных умений, навыков - все без исключения ответившие отметили, что предлагаемые методики, технологии, подход к решению экспертных вопросов может и должен быть внедрен в практику работы врачей-танатологов.

Анализ мнений о преподавании в разделе частных вопросов судебно-медицинской экспертизы показал, что одной из актуальных проблем для судебно-медицинских экспертов в практической работе является формулировка судебномедицинского диагноза, суждения о причине смерти. Лекционные и практические занятия, где разбираются вопросы структуры танатогенеза, примеры формулирования вывода о причине смерти, о причинно-следственных связях повреждений и осложнений, респондентами оценены исключительно на «хорошо» и «отлично».

С другой стороны, в качестве объективной оценки результативности и эффективности работы преподавателей кафедры судебной медицины со слушателями цикла могут выступать динамические показатели уровня знаний по результатам входного и выходного тестового контроля. Ана- 
лиз результатов тестирования продемонстрировал положительную динамику при сравнении среднего балла, полученного курсантами за ответы на вопросы входного и итогового тестового контроля, что позволило сделать вывод об эффективности работы со слушателями в целом и оценить результат работы кафедры как положительный.

По итогам аналитической работы сформулированы корригирующие мероприятия, направленные на устранение выявленных в ходе анализа недостатков преподавания и организации обучения, и выполненных при проведении следующего цикла усовершенствования. Результатом корригирующих мероприятий стал более высокий оценочный балл того раздела работы, на совершенствование которого и были направлены усилия преподавателей.

\section{Выводы}

1. Дополнительная профессионально-образовательная программа «Вопросы патоморфологии и судебно-медицинской оценке некоторых заболеваний и состояний» по специальности «Судебно-медицинская экспертиза» на кафедре судебной медицины УГМА обсуждена и одобрена ученым советом ФПК и ПП (протокол № 5 от 27.01.2012 г).

2. Организация цикла дополнительного профессионального образования осуществлена с учетом мнений врачей судебно-медицинских экспертов, а также основных потребителей продукции деятельности судебно-медицинской службы.
3. Используемая программа дополнительного профессионального образования по специальности «Судебно-медицинская экспертиза» отвечает всем современным требованиям в сфере высшего профессионального образования, сформулирована с использованием научного, процессного и системного анализов, основывается на компетентностном подходе, является гибкой и модульной.

4. Интеграция научной, практической и учебной деятельности на кафедре судебной медицины позволила максимально учесть при подготовке цикла общего усовершенствования проблемы судебно-медицинской экспертной практики, использовать материалы научной и практической работы в ходе занятий.

5. Динамика показателей контроля уровня знаний слушателей цикла (по результатам входного и итогового тестирования) демонстрирует высокую эффективность подготовки специалистов судебно-медицинских экспертов на цикле общего усовершенствования «Вопросы патоморфологии и судебно-медицинской оценки некоторых заболеваний и состояний».

6. Используемые кафедрой судебной медицины УГМА статистические методы обработки данных позволяют объективизировать и представить достоверную картину динамики показателей работы кафедры, стать научной основой для принятия решений по оптимизации педагогической деятельности.

\title{
ПРИКЛАД МОДЕЛІ ФОРМУВАННЯ ПРОГРАМИ ДОДАТКОВОЇ ПРОФЕСІЙНОЇ ОСВІТИ ЛІКАРІВ ЗА СПЕЦІАЛЬНІСТЮ «СУДОВО-МЕДИЧНА ЕКСПЕРТИЗА»
}

\section{С.Л. Соколова, О.Б. Долгова, Н.В. Пермякова, Г.А. Вишневський}

Резюме. У роботі наведено приклад формування програми додаткової професійної освіти за спеціальністю «Судово-медична експертиза» 3 урахуванням поглядів споживачів освітніх послуг і потреб експертної практики, представлено досвід реалізації програми.

Ключові слова: додаткова професійна освіта, судово-медична експертиза.

\section{EXAMPLE OF A MODEL OF FORMATING A PROGRAM OF ADDITIONAL PROFESSIONAL EDUCATION OF DOCTORS IN THE SPECIALITY "FORENSIC MEDICAL EXAMINATION"}

\section{S.L. Sokolova, O.B. Dolgova, N.V. Permiakova, H.A. Vishnevsky}

\begin{abstract}
The paper presents an example of forming a program of additional professional education in the speciality "Forensic Medical Examination", taking into account the opinion of consumers of educational services and requirements of expert practice, the experience of implementing the program is presented.

Key words: additional professional education, forensic medicine.

Ural State Medical Academy (Yekatyerinburg, Russia)

Рецензент - проф. В.Т. Бачинський

Buk. Med. Herald. - 2013. - Vol. 17, № 3 (67), part 1. - P. 161-163

Надійшла до редакції 05.06.2013 року
\end{abstract}

( С.Л. Соколова, О.Б. Долгова, Н.В. Пермякова, Г.А. Вишневский, 2013 